\title{
Negativity in political news: A review of concepts, operationalizations and key findings
}

Journalism

13(2) 179-202

(C) The Author(s) 2011 Reprints and permission: sagepub. co.uk/journalsPermissions.nav DOI: I0.I |77/|4648849| |427800 jou.sagepub.com

\section{Günther Lengauer}

University of Innsbruck, Austria

\section{Frank Esser}

University of Zürich, Switzerland

\section{Rosa Berganza}

Universidad Rey Juan Carlos, Spain

\begin{abstract}
The concept of negativity in political news has not reached the status of a homogenous, overarching theoretical concept. This article proposes conceptual understandings, categorizations and practical operationalizations of negativity in the news that reflect the consensus of existing work paying special attention to recent European research. This work aims to systematize existing concepts and categories in order to increase comparability and cumulativity of empirical evidence. To structure and standardize dimensions of negativity in the news we differentiate firstly between negativity and confrontation, secondly between frame-related negativity and individual actor-related negativity, and thirdly between non-directional and directional dimensions of negativity. This article provides a common set of indicators and matrice-based classifications of negativity (and its antithesis) in the news to measure and categorize its intensity and multi-dimensionality.
\end{abstract}

\section{Keywords}

conflict, content analysis, media coverage, media framing, negativity

\section{Corresponding author:}

Günther Lengauer, University of Innsbruck, AUTNES - Austrian National Election Study, Techniker St 2 la, ICT-Technologiepark, I. OG Nord, 6020 Innsbruck, Austria

Email: guenther.lengauer@uibk.ac.at 


\section{Introduction}

Investigations of 'negativity towards politics in the media' have become a core interest of communication and political science. Yet the concept of negativity in the news still lacks an agreed-upon conceptualization and operationalization. It appears in widely divergent manifestations which indicate the complexity and ambiguity of the concept (Kleinnijenhuis, 2008). Earlier research on the representation of politics in the news particularly negative ones - focused predominantly on the US American context (Bennett, 2009; Farnsworth and Lichter, 2011; Lichter, 2001; Niven, 2001; Patterson, 1994; Sabato, 1991; Zaller, 1999). So far, European scholarship on negativity in the news is more fragmented and less uniform in its conclusions since it reflects a greater diversity of political communication systems and research approaches. This makes it hard to say whether negativity is an exceptional US American media phenomenon (Schudson, 1999) or a generalizable trend all across modern mass democracies. Consequently, the universal validity and applicability of confrontational and negative reporting patterns is still in question (Gunther and Mughan, 2000). So far, although frequently applied in content analyses, no agreed-upon set of empirical indicators has emerged to reliably measure the concept of negativity in political news in a consistent and comparable way (Ridout and Franz, 2008). This has led empirical studies to draw widely varying conclusions about its significance and potential effects. Whereas some stress that confrontational news has an important information value, stimulates mobilization and contributes to healthy skepticism (De Vreese and Tobiasen, 2007; Freedman and Goldstein, 1999; Norris, 2000; Schuck et al., 2010; Weintraub and Pinkleton, 1995), others have linked adversarial reporting to a 'spiral of cynicism' (Cappella and Jamieson, 1997). This latter research relates negative news to a decrease in political engagement (Bennett, 2009; Patterson, 1994, 2002; Sabato, 1991) as well as skepticism and distrust towards political institutions and politicians (Moy and Pfau, 2000; Rozell, 1996). From scandal coverage to feeding frenzies (Sabato, 1991), confrontational and negative political news is thought to have serious repercussions for the way citizens perceive politics, especially for non-partisans or less-educated people (Berganza, 2008; Valentino et al., 2001).

In this article, however, we do not focus on presumed effects but on actual content features of negative news on politics. We propose conceptual definitions, operationalizations and concrete measurements for systematically gathering quantitative information on negativity in political news that may facilitate future cross-nationally comparative research (Esser and Pfetsch, 2004). Paying special attention to recent European scholarship, this article examines the existing content analysis literature and offers answers to questions such as: How can we conceptualize negativity in the news? How can we evaluate negativity in the news? How can we measure it, particularly with regard to framerelated and actor-related dimensions and to non-directional and directional dimensions of negativity? How can we assess previous findings, particularly with regard to the comparability of methods used and results yielded? How can we improve conceptual clarity, particularly in an effort to improve comparability and cumulativity?

The article concludes by suggesting a set of practical categories for content analysis that may aid future cross-national investigations of negativity in the news. Thus far, negativity has not reached the status of a homogenous theoretical and empirical concept. This article hopes to provide a contribution to this end. ${ }^{1}$ 


\section{Theoretical and conceptual foundations}

Scholars have offered different explanatory approaches towards negativity in political news. A mix of factors external and internal to the media is at play, and scholars thus often differentiate between the mere dissemination of negative news (exogenous negativity coming into the news from outside) and media-initiated negativity (endogenous negativity imposed on news by journalists).

\section{The evolution of negativity in the news}

The prevalence of negativity in the news can be explained by its evolutionary and discursive relevance. As an outcome of the evolutionary process, people are genetically wired to pay close attention to negative news and acquire a news-consuming habit to deviant individuals, ideas, and events. To the extent that deviant events represent threats to the status quo, the media may function as agents of social control when they publicize negative events: 'Publicizing deviance can set into action a corrective mechanism that punishes or eliminates the deviant actions' (Shoemaker and Vos, 2009: 47). Defenders of negativity also refer to the importance of debate, competing ideas, and conflict for the health of democracy. Criticism, counterargument and rebuttal increase the information available in decision-making situations and are legitimate and essential ingredients of political debate (Geer, 2006; Westen, 2007).

Political communication scholars do not take issue with these baseline explanations of why negativity is of inherent news value. However, scholars feel that further explanations are needed to account for the long-term intensification of negative news across countries and recent decades. These additional explanations point to (1) changes in the cultural and professional norms of journalists, (2) changes in the relationship between journalists and political public relations experts, and (3) changes in the competition and commercialization of the news business.

With regard to the first point, it is argued that increased levels of education among journalists (leading to more reflexivity and critical analysis in the news), a general shift toward post-materialist attitudes (Blumler and Kavanagh, 1999; Inglehart, 2000), and key events like Watergate, Vietnam and the 1968 protest movements contributed to a change in journalists' worldviews where negativity shifted from a mere 'news value' to an overarching 'news ideology' (Hallin and Mancini, 2004; Kepplinger, 2011: 117-37; Patterson, 2002: 63-98). This newly emerging 'critical journalism would strive to ensure that the troublesome aspects of society and the behavior of the holders of power would be under constant observation' (Westerstahl and Johansson, 1986: 137). In the 1960s and 1970s, a new ideal of 'critical scrutiny' emerged within the journalistic profession that concentrates on blunders in political strategy and mistakes in governing (Neveu, 2002). 'Critical' journalists will for every political statement seek a counter-statement from an opponent, and this 'degenerated' understanding of balance - at least in the view of Westerstahl and Johansson (1986: 147) - helped to create a more confrontational climate.

This brings us to the second point, the impact of political public relations. The new journalistic style of assertive, skeptical reporting and interpretation (as just described) turns at times adversarial when journalists feel threatened in their reporting options. In 
order to protect their professional integrity and their public image as an independent institution, journalists have grown increasingly critical toward pro-active news management and manipulative message control by political communication experts. The professionalization of political advocacy and spin has led to 'countermeasures' on the part of journalists - often in the form of negative, deconstructive or even cynical news (Blumler, 1997; Kerbel, 1999; Zaller, 1999) - and contributed in the United States and Western Europe to a 'démontage of politics' in public affairs coverage (Kepplinger, 1998; Patterson, 1994).

Criticizing politicians openly helps journalists to convey an image of independence and professional autonomy. This brings us to the third point, the impact of competition and commercialization. Aggressiveness towards political protagonists serves as a strategy to foster legitimization towards the public, and to maximize the audience (Benson and Hallin, 2007; Dunaway, 2009). This gives negative news an economic and instrumental value in the struggle for people's attention. Conflict-centered negativity is more 'marketable' than positive news as it is more eye-catching, adds drama, stimulates interest, and is easy to understand even by uninformed audiences. Cohen (2008: 89-134) finds that as news organizations feel greater economic pressures, they turn increasingly to negative news as a way of increasing audience size. We conclude that the biological and discursive value of negative information is undisputed and important. Most of the research reviewed in the following of this articles was, however, triggered by a recent expansion in negativity - induced by cultural, professional, interactional, and commercial dynamics in political journalism - that is assumed to contribute to a 'darkening of the political event horizon' in the media (Kepplinger, 2011).

Although there is vast agreement on the significance of negativity in contemporary news, it is widely contested who is to blame for it. Is it the journalist who adds controversy for professional, commercial or even political motives, or is it the politician who - at least partly in anticipation of the attractiveness of controversy as news value - frames the political discourse accordingly (Berganza et al., 2010; Brants et al., 2010; Kepplinger, 1998; Van Aelst et al., 2008; Westerstahl and Johansson, 1986; Zaller, 1999)? Besides professional and commercial reasons, opposing worldviews between media actors and political actors may contribute to negative bias in media content (Kleinnijenhuis, 2008). On the part of political journalism this may be the result of institutional (editorial policy of newsrooms) or individual (personal attitudes of journalists) animosities. Above all, actor-related negativity and partisan bias in journalism may be triggered by adversarial norms and attitudes (D'Alessio and Allen, 2000; Flegel and Chaffee, 1971; Kahn and Kenney, 2002; Kepplinger, 2011: 51-2; Kerrick et al., 1964). This kind of negativity is clearly media initiated.

Although a differentiation between media-initiated negativity (added by journalists) and media-disseminated negativity (triggered by others) is a fruitful and crucial question, for analytical but also methodological reasons it seems increasingly doubtful whether these two sides can be satisfactorily disentangled in standalone media content analyses especially if source information is left unquoted and used only as background material. ${ }^{2}$ From our point of view, the news story that is presented to the audience is first and foremost a journalistic product in its entirety, where the journalist had literally the last word in deciding which sources to quote and which criticism to include. Without ignoring the 
theoretical importance of the source-media relationship, we decided to disregard the distinction between media-intended and media-disseminated negativity (as it cannot be resolved by means of content analysis) and refer in the course of this article to negativity in the news as such.

\section{Operational manifestation of negativity in the news}

Measurement in quantitative content analytic research can be defined as the process of linking certain aspects of textual data to numerical values that represent the presence, intensity, and frequency of textual aspects relevant to communication research. Regarding the coding unit, previous studies captured dimensions of negativity in statements (Balmas and Sheafer, 2010; Brandenburg, 2005; López-Escobar et al., 2008; Zaller, 1999), paragraphs (Patterson, 1994) or on the story level (Patterson, 2000; Semetko and Valkenburg, 2000; Strömbäck and Dimitrova, 2006). As negativity appears to be insensitive to diverging recording units (Engesser and Reinemann, 2001; Zaller, 1999), we suggest that efforts to standardize coding should focus on a single layer only, the story level. This is also in line with the suggestions made for measuring the other concepts discussed in this Special Issue.

Several recording units can be distinguished to measure negativity at the story level: some are 'frame' related, others are 'actor' related. In the section that follows, we examine at the 'actor' level the tonality directed towards specific political representatives (or their organizations) in media reports. At the 'frame'-related level, we examine various storyline framing packages that form the narrative structure of reports.

\section{Frame-related dimensions of negativity}

Generic frames serve as a point of departure for identifying viable conceptual and operational dimensions of negativity in the news. These are not connected to specific issues or actors (which distinguish them from our actor-based concepts introduced later) and they are not bound to objective characteristics of events (which distinguish them from news values). Generic frames rather 'transcend thematic limitations and can be identified in relation to different topics, some even over time and in different cultural contexts' (De Vreese, 2005: 54).

I. Negative tonality of the story. A political report can be classified as being predominantly positive or negative in tone, irrespective of specific topics or actors discussed and involved. Individual evaluations of candidates and parties may be diverse within one report, but the overall tone abstracts from these actor-related details and reflects the summary picture. For determining the overall tonality of a story, researchers used singular questions such as 'whether the story on the whole falls in the good news or bad news category' (Patterson, 2000: 25) or 'in your opinion, what is the overall tone of the story?' (Dunaway, 2009: 15). Potential explicative indicators of a predominantly negative tone are, for example, retrospective, concurrent, or prospective accounts on disastrous, threatening, disputing, criticizing, fiasco-centered discussions or references to defeatism. On the other hand, depictions of political success, achievement or prosperity may serve as indicators of a predominantly positive portrayal of politics. Similarly, Just et al. labeled 
the tone as a bipolar indicator depicting 'overall political cynicism or idealism' (1999: 28). They defined idealistic messages as expressing 'vitality, optimism, or excitement' and cynical messages as 'pessimistic and contained jaded perspectives or portrayed selfinterested motivations'. Whereas the operational definitions of tonality differ significantly, earlier studies broadly agree on rating scale measures based on bipolar semantic differentials. Scales that bipolarly project negative, ambivalent or neutral and positive tones are implemented most frequently. These ratings usually range between three- and six-point scales, by separating or conflating ambivalent and neutral classifications (Benson and Hallin, 2007; Dunaway, 2009; Just et al., 1999; Lengauer, 2007; Lengauer and Vorhofer, 2010; Patterson, 2000; Plasser et al., 2009; Sheafer and Gabay, 2009).

2. Pessimistic outlook in the story. A sub-dimension that appears in earlier research and further specifies the overall tone refers to the prospective dimension of political reporting. The outlook of a story bipolarly refers to political expectations that are anticipated in news reports (Kepplinger, 1998; Lengauer, 2007). A story is framed in optimistic terms if it primarily conveys the impression that positive developments are likely or possible, or if the problems at hand are solvable. A story's outlook is pessimistic if it conveys the overall impression that negative, critical and threatening scenarios are likely or possible, or if the problems at hand are unlikely to be resolved (Lengauer and Vorhofer, 2010). The operational definitions of political outlook rely on bipolar generic frames with scales that either range from +2 (clearly optimistic) to -2 (clearly pessimistic) (Kepplinger, 1998) or from +1 (predominantly optimistic) to -1 (predominantly pessimistic) (Lengauer, 2007; Lengauer and Vorhofer, 2010; Sheafer and Dvir-Gvirsman, 2010). In these studies the recording unit is again the whole report. Bipolar coding strategies allow simultaneous investigation of the antitheses of negative tonality and pessimistic outlooks.

Now we turn to the 'confrontational' dimension of negativity on the frame level. Earlier conceptualizations of 'confrontation' as the directional form of negativity reach from sheer critique, mutual attacks, metaphors of combat and battlefield to allegations of scandals and misconduct (Patterson, 1994; Sheafer et al., 2008). Confrontational reports can depict one-sided (only addressing one or more accused), two-sided or multi-sided disputes (involving accusers and accused). Here, we define conflict as a two- or moresided confrontation, whereas unidirectional allegations, attacks and scandals are classified as one-sided manifestations of confrontation.

3. Story focus on conflict. In our understanding a conflict is given when an at least twosided dispute is displayed. An array of studies investigated the magnitude of dispute and controversial coverage on politics (Canel et al., 2007; Neuman et al., 1992; Patterson, 1994; Semetko and Valkenburg, 2000; Strömbäck and Dimitrova, 2006). The concept of conflict reflects a rather discrete dimension of negativity that represents the confrontational but not per se destructive dimension of framing politics (De Vreese and Tobiasen, 2007). Depictions of conflict emphasize dispute between individuals, groups, institutions, or political views as a means of capturing public interest. Operational definitions of conflict given in publications reach from 'journalistic practice of reporting stories of clashing interpretation' (Neuman et al., 1992: 64), 'substantial level of conflict in the 
news story (yes/no)' (Strömbäck and Dimitrova, 2006; Strömbäck and Luengo, 2008), 'does the news item focus on external (or internal) party disputes (yes/no)' (Shenav and Sheafer, 2008), to multi-dimensional concepts not necessarily differentiating the origins and generators of conflict. For example, Semetko and Valkenburg (2000) applied the following four binary yes/no questions to identify the level of conflict in news of European politics: (1) 'Does the news story reflect disagreement between parties, individuals, groups, countries?'; (2) 'Does one party, individual, group, country reproach another?'; (3) 'Does the news story refer to two sides or to more than two sides of the problem or issue?'; (4) 'Does the story refer to winners and losers?' (see also De Vreese, 2005). By answering these questions with 'yes' (code 1) and 'no' (code 0 ), they developed a conflict index ranging from ' 0 ' (not conflictual) to ' 1 ' (highly conflictual). ${ }^{3}$ Alternatively, the generic conflict frame also appears as a bipolar indicator, reaching from conflict to consensus and being operationalized as a, at least, tripartite rating scale (e.g. conflictcentered, ambivalent, consensus-centered). ${ }^{4}$ This continuum-based approach simultaneously allows the measuring of levels of conflict and its antithesis. Consensus- and cooperation-oriented stories usually have a clear emphasis on (potential) agreement among players (Canel et al., 2007; Lengauer, 2007; Lengauer and Vorhofer, 2010; Project for Excellence in Journalism, 1998).

4. Story focus on incapability and misconduct. Whereas conflict and controversies involve at least two sides, one-sided confrontational depictions may manifest themselves as unidirectional accusations, ranging from mere critique to straight attacks and allegations of scandalous misconduct. Few previous studies operationalized this dimension of one-sided accusations as a bipolar generic frame contrasting capability and incapability, competence and incompetence, or legitimacy and illegitimacy (Kepplinger, 1998; Lengauer, 2007; Sheafer and Gabay, 2009; Wayne and Murray, 2009). Similar to the operationalization of conflict, the applied measures were based on three- or five-point rating scales representing both poles and referring to the framing of the story as such.

The most negative variant of incapability and failure is scandal reporting. Scandal reporting refers to uncovering violations of norms and allegedly immoral misconduct in a sensationalized and emotionalized way (Kepplinger, 1998; Lengauer, 2007). Strömbäck coded in this category stories that 'focused on alleged scandals involving politicians or political institutions, or if they framed what politicians said as if what they had said were a scandal, i.e. if the article focused on gaffes' (2005: 7). So far, the level of scandal reporting has mostly been measured in two different ways. Some studies used single yes/no questions such as 'Does the story portray alleged political wrongdoing and misconduct as scandalous?' (Strömbäck, 2005) or they used a keyword search looking for stories that contain terms like 'scandal*', 'corrupt*', 'conspire*', or 'convict*' (see Puglisi and Snyder, 2008). Again, other studies categorized the level of scandal reporting by defining a generic frame that is based on a bipolar rating scale. For example, Kepplinger (1998) and Lengauer (2007) applied three or five-point Likert scales to register levels of scandalized versus non-scandalous, de-escalating and unemotional framing of political stories.

So far we have identified measures of frame-related negativity in earlier research that relate to the overall tone and the level of confrontation in news items. We now turn to clearly individual and actor-related dimensions of negativity. 


\section{Actor-related dimensions of negativity}

5. Negative tone towards political actors and their organizations. The individual tone towards actors has to be analytically separated from frame-based indicators, which relate to the framing of politics on a narrative level. For actor-related negativity the coding unit remains the whole report, whereas the content unit is a specific individual actor, a group of individuals or an institutional actor.

In past research there evolved a broad variety and inconsistency in the use of measure and labels for actor-related negativity, ranging from 'slant' (Kahn and Kenney, 2002), 'bias' or 'statement bias' (D'Alessio and Allen, 2000) to 'favorability' (Brandenburg, 2005), and 'tone' (Wilke and Reinemann, 2007). However, most research fails to provide comprehensive definitional explanations (see D'Alessio and Allen, 2000). Accordingly, the labels for the most commonly used semantic differentials range from unfavorable to favorable, from adversarial to supportive, or from positive to negative. Consequently, comparability across studies and cumulativity of empirical evidence is severely restricted.

Definitions of bias, slant, and favorability usually refer to 'individual news reports and editorials in which the framing favors one side over the other in a current or potential dispute' (Entman, 2007: 165), and mostly accentuate the genuine journalistic contribution. In the practical coding process this context-dependent approach can be a challenge for coders and may yield unreliable results. In contrast, definitions of (intersubjective) tone do not presuppose to take an actor-specific standpoint and instead relate to more manifest evaluative references towards political actors. Consequently, we prefer the latter coding approach, focusing on explicit and intersubjective positive and negative indicators regarding the tone towards actors. This relates to explicitly positive and negative references towards political actors, which may derive from journalists themselves as well as their sources. The main point against applying context-related favorability measures in content analyses is the same as for not differentiating between media-intended and not media-intended negativity. Reliable coding of favorability requires comprehensive knowledge about a politician's interests and strategic intentions and about the journalists' motives for their evaluations in order to determine correctly whether a 'story treatment' is in the politician's favor or not. Therefore, we take the position that coding of actor-related negativity should be primarily based on manifest and objectifiable indicators of tone and less on hermeneutic (and sometimes necessarily speculative) interpretations of favorability.

Rating scales of tone usually include a 'neutral' category, capturing also non-evaluative reports regarding specific political actors (Brandenburg, 2005; Druckman and Parkin, 2005; López-Escobar et al., 2008). Additionally, many studies differentiate between ambivalent and neutral coverage (Kahn and Kenney, 2002; Lengauer, 2007). A viable, index-based way of measuring tone has been proposed by Brandenburg (2005) and Lengauer and Vorhofer (2010). They computed a mean-based index from a scale that ranges from +1 (positive tone), 0 (ambivalent or neutral) to -1 (negative tone). This index allows an actor's tone to be summarized across news stories in the form of a single score that merges all evaluative (positive, negative, ambivalent) and non-evaluative 
(neutral) dimensions into one measure. Such a bipolar, index-based coding strategy gives rise to a matrix that facilitates the comparative categorization and location of diverging levels of negativity toward different political actors.

After outlining dimensions of negativity identified in earlier studies, we now turn to their key findings.

\section{Key findings}

I. Negative tonality of story. Negative tone in political reporting is not a recent but a longrunning phenomenon. However, the empirical evidence is rather scarce and scattered, as most previous studies deduced the overall tonality from the aggregation of individualized tone towards candidates or parties (Eshbaugh-Soha, 2010; Lichter, 2001; Niven, 2001; Wilke and Reinemann, 2007) or derived levels of negativity directly from conflict measures (Vliegenthart et al., 2011). Turning to the empirical evidence, Kepplinger (1998) finds, for example, that between 1951 and 1995 the German quality press constantly focused more on failure than success in German politics (for German radio see Kepplinger, 2011: 117-37). Looking at TV election news in the USA, Germany and Austria, Lengauer (2007) finds that the negative tone clearly outweighs the positive tone with a ratio of about 10 to 1. Negative tone ranges from one-third on Austrian and German TV to almost half of all reports on $\mathrm{ABC}$ News. However, a relative majority of all reports in the three countries is still neutral in tone. Plasser et al. (2009) comparatively analyzed the US 2004, the German 2005 and the Italian and Austrian 2006 TV campaign coverage, and they come to similar conclusions: bad news on politics amounts to roughly half the reports in all countries, whereas good news only emerges in between 6 percent (USA, Austria, and Germany) and 15 percent (Italy) of all reports.

2. Pessimistic outlook in story. That a negative tone is frequently substantiated by pessimistic outlooks on politics across countries is confirmed by Lengauer's (2007) cross-national and Lengauer and Vorhofer's (2010) mono-national investigations of election coverage. These studies demonstrate that pessimistic views on politics dominate over optimistic outlooks across countries and media outlets. And this has prevailed more or less over time, for example in Germany (Kepplinger, 1998). Despite the well-established supremacy of pessimistic over optimistic reports during and beyond election campaigns, it must be acknowledged that a great deal of political reporting is still neutral in tone (De Vreese, 2008).

3. Story focus on conflict. One of the few longitudinal studies on conflict draws on Norwegian and Swedish campaign coverage from the 1950s to the 1990s. In this study, Sandnes (2004) identifies an increase in the emphasis on portrayals of conflict in the political news from the 1950s onward, culminating in the 1970s. Outside election campaigns, the Project for Excellence in Journalism (1998) shows for the US that portrayals of conflict in daily papers clearly outweigh consensus depictions in front-page stories, with prestige papers being most conflict centered. On a cross-nationally 
comparative level, Plasser et al. (2009) observed that conflict in election news on TV is highest on Italian TV, followed by Austria, US and German TV. Contrastingly, consensual portrayals of politics during election campaigns hardly reach 10 percent of the coverage in any country. Another comparative study on generic conflictual and cooperational framing on public service TV news in Spain, Germany, and Italy finds a similar transnational preference for conflict news (Canel et al., 2007).

Many scholars examined conflict news in the European context. High and robust levels of controversial reporting were found in a longitudinal analysis of Dutch campaign coverage in newspapers and on TV (Kleinnijenhuis et al., 2007). In the specific context of the European Union, conflict emerges as a fundamental frame in the British, Danish, and Dutch news coverage referring to the introduction of the Euro (De Vreese, 2005), the Dutch coverage of the EU summit in Amsterdam (Semetko and Valkenburg, 2000), or the Spanish media coverage of the referendum campaign about the EU Constitution or European elections (Berganza, 2008, 2009), to name just a few. Similar results were found by one-country studies on how national general elections were covered, for example in Sweden (Strömbäck, 2008a), Austria (Lengauer and Vorhofer, 2010), or the USA (Neuman et al., 1992). In all cases, conflict-focus levels vastly outweigh consensus news. Conflict appears as a powerful framing device across countries, media systems, media formats and phases of the political process.

4. Story focus on incapability and misconduct. In his longitudinal content analysis Kepplinger (1998) finds a continuous rise in reports on unresolved political problems and incapability in the German press, outweighing reports on solutions and capability by a ratio of three to one in the mid 1990s. In the same vein, Plasser et al. (2009) show that general political incapability is highlighted more often than political capability in the election coverage of Austria, Germany, Italy and the USA in the early 2000s.

For the Swedish election campaigns from 1998 to 2006, Strömbäck (2008b) notes a moderate increase of scandal coverage in quality and tabloid papers as well as on public service and commercial TV news. However, quality press and public service television framed politics as less scandalous than commercial TV and tabloids. Kepplinger (1998) also examines the levels of political attacks and scandal reporting in the German quality press. He finds a moderate increase between 1951 and 1995, but characterized by high fluctuation. For the Israeli elections from 1996 to 2006, Sheafer et al. (2008) also state a marked increase of reported attacks and criticism towards politics in television news.

5. Negative tone towards political actors and their organizations. In two long-term analyses of political television and press coverage in the United States, Patterson (2000: 10; see also Patterson, 1994) and Zaller (1999) demonstrate that negative references to presidential candidates in the coverage tripled between 1960 and 2000, and that they outnumber positive references since the late 1970s. This trend is corroborated by studies that examined negative candidate portrayals in several individual US presidential campaigns (Eshbaugh-Soha, 2010; Just et al., 1999). Parallels to the US patterns were found by two long-term analyses in Germany which report an increase in negative statements about politicians since the 1950s in and outside election campaigns (Kepplinger, 1998; Wilke 
and Reinemann, 2007). The comparative study by Plasser et al. (2009) also shows that TV election news - albeit predominantly neutral - brings a lot more negative frontrunner related evaluations than positive ones. This corroborates De Vreese et al. (2006) who looked at election news in 25 countries in relation to European Parliament elections and found that news was overwhelmingly neutral towards the EU institutions and actors, but if evaluative then by and large negative. Additional research on Ireland and Austria capturing the relative tendency towards political protagonists (mean of positive, neutral/ambivalent and negative reports) also interprets their evidence as a holistically negative tone in reporting on candidates, party leaders, and party organizations (Brandenburg, 2005; Lengauer and Vorhofer, 2010).

We conclude that with very few exceptions (e.g. Salgado, 2010) the existing body of evidence hints to predominant, increasing, and overarching negativity towards individual political protagonists and parties. However, more directly comparative approaches and concerted conceptualizations and operationalizations are desirable for future research to substantiate or even qualify these conclusions drawn from earlier studies. This requires progress in conceptual clarity and operational standardization.

\section{Towards conceptual clarity}

A central goal of this essay is to propose a conceptual understanding, categorization and practical operationalization of negativity in the news that on the one hand reflects the consensus of existing work and on the other hand can serve as a guideline for future work. To increase comparability of results, future researchers may have an interest in a certain degree of standardization of concepts and categories. To systematize negativity in the news we firstly differentiate between frame-related negativity that originates from characteristics of the narrative overall structure (generic frames) and individual actorrelated negativity that manifests itself in portrayals of political actors' individual performance (i.e. of parties, candidates). By bringing previously isolated indicators together and arranging them along these two dimensions we constructed a categorization of negativity as illustrated in Table 1. On the frame-related level of negativity we further differentiate between directional and non-directional manifestations of negativity. Thereby, non-directional negativity refers to framing devices such as tonality (negative vs positive tone) or outlook (optimistic vs pessimistic prospect). These indicators are not directed to specific actors, but refer to negativity in the depiction of politics in the story line. Different from that, directional negativity draws on news framing that explicitly involves an accuser and addressee and thus predominantly represents the aspect of confrontation. These framing devices reach from one-sided criticism, attacks, and alleged scandals, which we conceptualize as incapability and misconduct to two-sided manifestations of these dimensions as conflict. Whereas non-directional negativity on the frame level refers to the generic manifestation of tonality, directional negativity reflects confrontation. Detailed operationalizations and coding instructions follow in the next section and the appendix.

From Table 1 (and what follows) readers will notice that we strongly favor bipolar over unipolar measurements. Although we apply 'negative' labels such as negative 
Table I. Dimensions of negativity in the news

\begin{tabular}{|c|c|c|}
\hline & FRAME-related Negativity & ACTOR-related Negativity \\
\hline $\begin{array}{l}\text { Non-Directional } \\
\text { Negativity (OVERALL } \\
\text { TONE) }\end{array}$ & $\begin{array}{l}\text { Level of Negative Tonality } \\
\text { (ranging from negative to positive } \\
\text { tonality) } \\
\text { Level of Pessimistic Outlook } \\
\text { (prospect ranging from pessimistic } \\
\text { to optimistic views) }\end{array}$ & \\
\hline $\begin{array}{l}\text { Directional Negativity } \\
\text { (CONFRONTATION) }\end{array}$ & $\begin{array}{l}\text { Level of Conflict-Centeredness } \\
\text { (conflict vs. consensus - reflecting } \\
\text { at least two-sides) } \\
\text { Level of Incapability and } \\
\text { Misconduct } \\
\text { (incapability vs. capability - includ- } \\
\text { ing one-sided criticism, attacks, al- } \\
\text { legations as well as commendation) }\end{array}$ & $\begin{array}{l}\text { Level of Negative Tone } \\
\text { towards Actor A, B, C ... } \\
\text { (individual tone; ranging from } \\
\text { negative to positive tonality) }\end{array}$ \\
\hline
\end{tabular}

tonality, pessimistic outlook, conflict-centeredness, and incapability, we suggest measuring levels of negativity with categories that include both polar opposites of the concept: negative vs positive tonality, pessimistic vs optimistic outlook, conflict vs consensus orientation, incapability vs capability.

Returning to the broader classifications in Table 1, it is worth stating that the proposed theoretical distinction between 'overall tone' and 'confrontation' has received empirical support by way of a factor analysis which suggested that conflict and incompetence form a distinct framing cluster that emerges fairly independently of tone and outlook in election news (Lengauer and Vorhofer, 2010). Further research is needed to substantiate this classification.

How might a data analysis strategy look that works with the measures introduced in Table 1 (and specified in the next section and the appendix)? We begin with frame-based negativity, which, as shown before, consists of two basic dimensions, overall tone and confrontation. This yields a quadrinomial matrix with four types of confrontational negativity, each representing a different level of intensity and dimensionality (see Figure 1). Analogously, we can build a similar two-dimensional matrix referring to the actor-related dimensions of negativity, combining and simultaneously contrasting the tone towards collective actors (e.g. parties) and individual actors (e.g. candidates, leaders, front runners) as depicted in Figure 2. By distinguishing between the tones towards institutions and individuals, scholars can categorize different intensities and directions of negativity on the actor-related dimension. 


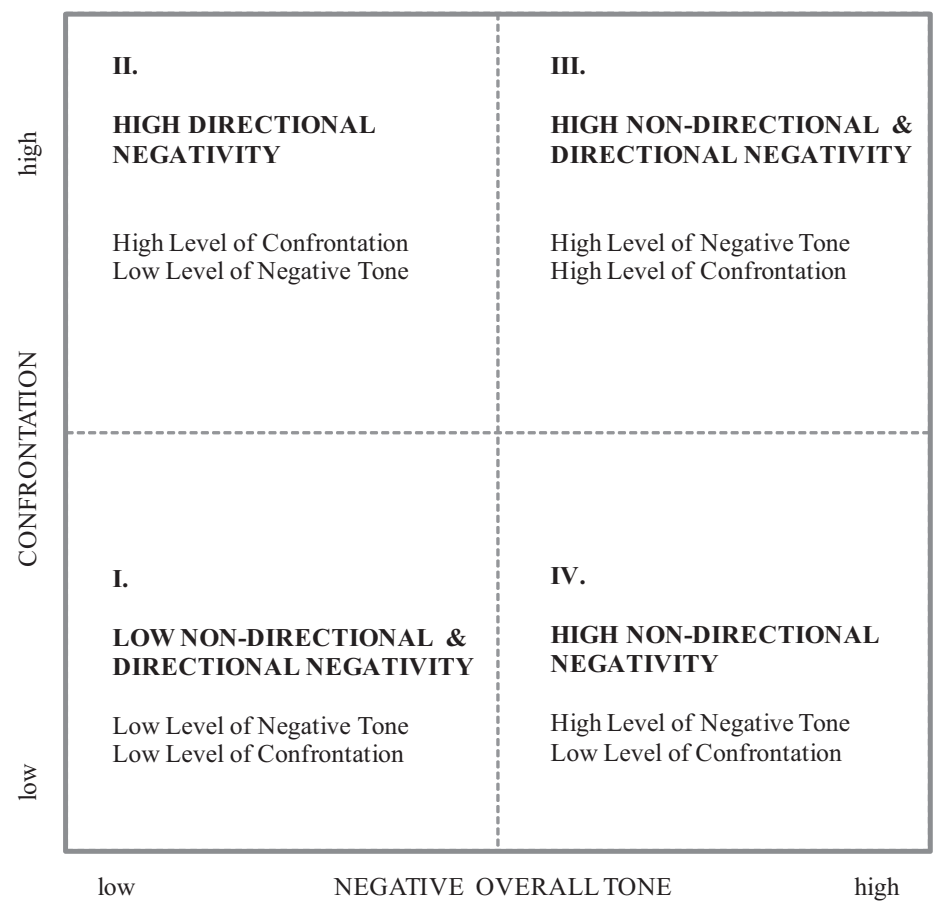

Figure I. Matrix of actor-related negativity in the news

These quadrinomial matrices meet the absolute and relative dimension of the concept of confrontational negativity as introduced here. They firstly reflect the absolute level of comparison by bipolarly outlining and measuring both confrontational negativity and its antithesis, and they secondly also meet the relative level of comparison by setting out clusters of diverging levels of frame-related confrontational negativity and actor-related negativity toward parties and candidates (see Figures 1 and 2). Additionally, simple cumulative indexing keeps these matrices flexible, extendable, and reducible to various numbers of indicators and actors within one dimension. The benefit of these matrices, we believe, is that they allow data on negativity and its antithesis to be comparatively categorized across time and systems, and across routine phases and election phases. They help assess the extent to which politics in the news is predominantly negative and confrontational (regarding generic framing and actors), and display the multi-dimensional manifestations in which negativity emerges (directional vs non-directional negativity; frame-related vs actor-related negativity). Figures 1 and 2 are thus meant to serve as heuristic templates. By structuring empirical data from different settings and time points along these negativity clusters, findings become classifiable and comparable. This may set an empirical baseline for future research. 


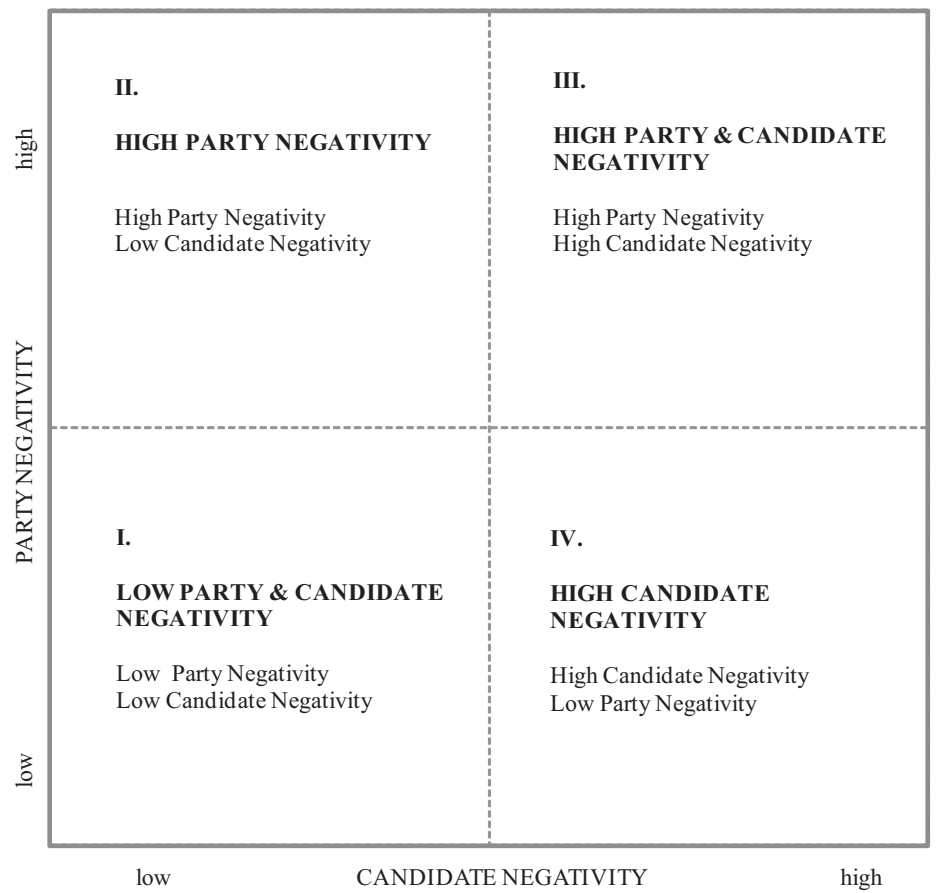

Figure 2. Matrix of actor-related negativity in the news

Note: The empirical categorization of 'high' and 'low' is index-based. 'High' refers to the dominance of negative and confrontational news over positive and consensus-driven news. 'Low' refers to the dominance of the respective antitheses which are 'positive overall tone', 'consensus-centered reporting', 'candidate positivity', and 'party positivity'. The corresponding index-based operationalizations and measures are given in the coding instructions in the Appendix.

\section{Towards increasing comparability and cumulativity}

The closing section of this article suggests definitions and operational measures that aim to facilitate standardized and comparative investigations. We propose a basic set of indicators and operationalizations that fit our two introduced matrices to measure levels of confrontational negativity in the news. These indicators can be applied to different media outlets, journalistic genres, phases of election campaigns and political routine. Their consistent use may reduce methodological deviations and artificially evoked variations in findings.

Existing indicators have been predominantly operationalized in three different ways: (1) binary coding strategies, based on single questions; (2) binary coding strategies, based on a set of questions resulting in multi-dimensional indexing; (3) bipolar coding strategies, based on a single semantic differential. Binary coding (yes/no questions) has the advantage of reaching high levels of intercoder reliability (Semetko and Valkenburg, 2000). A common binary coding strategy rests on a set of yes/no questions that result in 
multi-dimensional indexes. These strategies have been widely applied for investigating various frames, including conflict (De Vreese, 2005) and constructing standardized indices on this basis. The disadvantage of such unidirectional binary proceedings, however, is that the analysis remains mainly unipolar and disregards the concept's antithesis (which may be more prevalent in the news without ever being known).

Although bipolar coding is characterized by high cognitive complexity (Van Gorp, 2005: 503; see also Matthes and Kohring, 2008), we take this approach to propose a promising operational standardization in measuring negativity in the news. Bipolar coding is applicable for measuring frame-based indicators such as conflict or incompetence, but also to capture the tone towards politicians and parties. Additionally, Likert scalebased and thus continuum-related measures facilitate the categorization and location of empirical data in comprehensive scales ranging from one endpoint (thesis) to the other (antithesis). Consequently, we suggest uniform bipolar coding strategies for all confrontational negativity measures to enable the best possible model fitting and to minimize frictional losses in measurement.

Our proposed measurement is based on the nature of a three-point Likert scale, which represents the rating option with the minimal number of codes and the maximal quality of coding agreement, replicability and reproducibility (Roessler, 2005). The score ranges from -1 , which indicates that all reports are conflict driven, show negative tonality, reflect predominantly political incapability, and offer pessimistic views or negative portrayals of political actors, to +1 , in which all reports predominantly focus on consensus, positive tonality, capability, optimistic outlooks, or positive evaluations of candidates and parties. A score around 0 indicates neutrality, absence, or ambivalence towards the generic frame or the portrayal of the protagonist. In contrast to Goodman Kruskal Gamma (also ranging from -1 to +1 ), which excludes neutral and ambivalent characteristics and may be referred to as 'absolute tendency' (Maurer and Reinemann, 2006: 135), our proposed index purposely incorporates these undetermined measures (as ' 0 '). Such an approach controls for the general level of appearance of candidates, parties, and the status of specific generic frames in news reporting. As a consequence, this proposed mean, also labeled as 'relative tendency' (Maurer and Reinemann, 2006: 135), additionally considers 'neutral/no tendency' measures, yet puts them on a level with 'ambivalent' measures. Our indexing strategy is based on a simple cumulative logic that is flexible to varying numbers of indicators that are applied in all dimensions. ${ }^{5}$ A central advantage of this approach is that it can be applied to all kinds of recording units (statements, paragraphs or reports), as it may result in and can be aggregated to one single measure for the applied unit of analysis. ${ }^{6}$

\section{Conclusion and discussion}

This article reviewed the concept of negativity in the news, its empirical evidence and, derived from that, it suggests operational strategies to comparatively measure confrontational negativity and its antithesis in quantitative content analyses. We propose a conceptual understanding, empirical categorizations, and integrative operationalizations that 
reflect the consensus of existing work, paying special attention to recent European scholarship. As negativity has not reached the status of a homogenous theoretical and empirical concept, we contribute to this end by proposing conceptual and operational standardizations to increase comparability and cumulativity of empirical investigations on negativity and its antithesis in political news.

This work also offers concrete measurements and a set of practical indicators for systematically gathering quantitative information on negativity, which may serve as a guideline for future cross-national investigations by being applicable to different national and cultural contexts. Our proposed index-based matrices of confrontational negativity serve as heuristic templates setting a baseline for further research. This analytical framework is robust but still flexible (dimensionally extendable and reducible), it can be applied to measure changes and mutations of the concept over time, and is applicable to different kinds of media outlets, journalistic genres, political phases of elections, and routines.

To systematize negativity in the news we differentiate between frame-related negativity and individual actor-related negativity and also between non-directional and directional dimensions of negativity to lay out a robust framework for classifying different manifestations of negativity. By bringing previously isolated indicators together and arranging them along these dimensions we offer a common and extendable toolbox for measuring the intensity and multi-dimensionality of frame- and actor-related negativity and positivity in political news. This matrix-based framework, which differentiates between levels of negativity and confrontation, is also applicable to simple research designs, based on standalone content analyses.

However, our suggestions do not conclusively identify and disentangle the exogenous and endogenous sponsors of destructive views on politics in the media. More complex and integrated study designs are needed, which would control for contextual and campaign negativity over time, to comprehensively investigate this desideratum in political communication research.

As transparency of published studies is still underdeveloped, in quantitative content analysis research it should become a standard practice to enclose codebooks, coding instructions and testing results of reliability and validity. Only by ensuring full transparency can high levels of comparability, cumulativity and replicability be achieved, which in turn enhances the state of research in this field of study. Our proposed standards of operationalization should contribute to this end. This research and its conclusions are an attempt to enrich and systematize investigations in this area and serve as a starting point of discussion, adjustment, and refinement in order to gain higher levels of cumulativity and comparability of empirical evidence on negativity and its antithesis in political news. 


\section{Appendix}

\section{Coding instructions}

Coding instructions

\section{NON-DIRECTIONAL NEGATIVITY (OVERALL TONE)}

\section{Level of negative tonality}

What is the overall tone of the story? Does the report convey primarily a positive, negative, balanced or neutral impression of politics, political records, conditions or views?

\section{Level of pessimistic outlook}

Does the story convey primarily optimistic, pessimistic or balanced outlooks on politics or are no indications referring to political outlooks identifiable?
Indications of negative tonality are the framing of the story as political failure, fiasco, disaster, crisis, frustration, collapse, flop, denial, rejection, neglect, default, deterioration, resignation, skepticism, threats, cynicism, defeatism or disappointment. Indications of positive tonality are depictions of political success, problem solutions, achievement, improvement, advance, prosperity, accomplishment, enthusiasm, hope, benefit, gain, sustainability, gratification or accomplishment. If a report does not reflect indications of negative tonality or of positive tonality, then it has to be coded as 'neutral'. The variable has three codes:

$-I=$ predominantly negative tonality

$0=$ balanced/ambivalent/neutral

+ I = predominantly positive tonality

An optimistic depiction is given when the framing of the report generates the intersubjective impression that positive developments in politics are realistic, possible, or at hand (depictions of optimism, positive outlooks and scenarios, hopeful views, prosperous developments, potential gains, potential solutions or promising expectations). In contrast, pessimistic depictions are given when the framing of the report generates the impression that negative developments in politics are realistic, possible, likely or at hand (depictions of pessimism, negative outlooks and scenarios, hopeless views, critical developments, negative expectations or potential threats). If a report does not reflect indications of pessimistic or of optimistic outlooks, then it has to be coded as 'not applicable'.

The variable has three codes:

$-I=$ predominantly pessimistic outlook

$0=$ balanced/ambivalent/not applicable

$+\mathrm{I}=$ predominantly optimistic outlook 


\section{Appendix. (continued)}

Coding instructions

\section{DIRECTIONAL NEGATIVITY (CONFRONTATION)}

\section{Level of conflict-centeredness Does} the report convey primarily conflictual, consensus-centered or balanced impressions of politics, political records, conditions and views or are no indications referring to political conflict and consensus identifiable?

\section{Level of incapability and misconduct}

Does the report convey primarily indications of incapability, capability or balanced impressions of politics or are no elements referring to political incapability and capability identifiable?

\section{ACTOR-RELATED NEGATIVITY} (INDIVIDUAL TONE)

\section{Level of negative tone towards} political actors (persons or institutions) Does the report convey primarily a positive/affirmative, negative/ critical or balanced/neutral impression of a specific political actor or are no clear indications referring to the positive or negative tone towards political actors identifiable?
The conflict dimension refers to at least two-sided depictions of (attempts, initiation, completion of) dispute, disagreement, discordance, confrontation, clashing positions and views or controversy. The consensus dimension refers to at least two-sided depictions of (attempts, initiation, completion of) consensus, accordance, consonance, conformities, dispute settlements, agreement, willingness of cooperation, willingness to compromise, approval or reconciliation. If a report does not reflect indications of conflictcentered or of consensus-centered depictions, then it has to be coded as 'not applicable'. The variable has three codes:

$-I=$ predominantly conflict centered $0=$ balanced/ambivalent $/$ not applicable $+I=$ predominantly consensus centered The misconduct dimension refers to unidirectional and unilateral depictions of critique, criticism, attacks, allegations of misconduct, moralizing accusations, charge of wrongdoing, accusation of incapability or incompetence, affronts and insults. The competence dimension comprises unilateral depictions of commendation, accordance of capability or competence, compliment, acclaim, portrayals of merit or effectiveness. If a report does not reflect indications of incapability or of capability, then it has to be coded as 'not applicable'.

The variable has three codes:

$-I=$ predominantly incapability centered

$0=$ balanced/ambivalent/not applicable

$+\mathrm{I}=$ predominantly capability centered

Indications of a prevalent negative tone toward a specific political actor are depictions of individual failure, fiasco, disaster, crisis, frustration, miscarriage, collapse, flop, rejection, neglect, default, defeat, deterioration, resignation, disdain, received critique, criticism, attacks, scandal, moralizing accusation, allegations of misconduct, charge of wrongdoing, mistrust, accusation of incompetence or negative traits. Indications of a prevalent positive tone toward a political actor are depictions of individual victory, win, triumph, success, achievement, accomplishment, 


\section{Appendix. (continued)}

Coding instructions

problem solutions, improvement, advance, prosperity, laudation, asset, sustainability, commendation, accordance of competence, compliment, portrayals of merit, esteem, trust or positive traits. If a report does not reflect indications of negative tonality or of positive tonality towards the specific actor, then it has to be coded as 'neutral'. The variable has three codes:

$-I=$ predominantly negative tone towards the actor

$0=$ balanced/ambivalent/neutral tone towards the actor

$+\mathrm{I}=$ predominantly positive tone towards the actor

Note: 'Recording unit for all codes is the whole report. The identification may be based on direct (mediainitiated) and indirect (source-initiated) indications. References to the respective indicator might be retrospective, current, or prospective in nature. 'Predominantly' always refers to the opposite pole. In this case 'predominantly negative' means that negative framing dominates over positive framing. The report is coded as 'neutral/not applicable' when neither negative nor positive indications emerge in the report. This principle is applied to all here-presented indicators of negativity in the news.

\section{Notes}

1 This research was partly carried out under the auspices of the Austrian National Election Study (AUTNES), a National Research Network (NFN), sponsored by the Austrian Research Fund (FWF) (S10904-G11).

2 This conclusion dates back to an old debate between Galtung and Rosengren on the question of whether extra-media data were a requirement to delineate which part of the intra-media data was based on sources and real facts (see Galtung and Ruge, 1965; Rosengren, 1974). Although Zaller (1999) introduces some useful distinctions he cannot resolve this problem.

3 Ultimately, the winning/losing statement did not mount up to Semetko and Valkenburg's conflict index as it did not meet the correlative threshold set by the authors.

4 Mostly the scale is extended by a code 'not applicable' which is equivalent to 'neutral' measures in the overall tonality.

5 The sum of the means of all bipolar indicators is divided by the total number of indicators (of one dimension).

6 The sum of codings of statements/paragraphs/reports $(-1,0,+1)$ is divided by the total number of statements/paragraphs/reports (of one actor).

\section{References}

Balmas M and Sheafer T (2010) Candidate image in election campaigns: Attribute agenda setting, affective priming, and voting behavior. International Journal of Public Opinion Research 22(2): 204-229. 
Bennett LW (2009) News: The Politics of Illusion, 8th edn. New York: Longman.

Benson R and Hallin DC (2007) How states, markets and globalization shape the news: The French and US national press, 1965-97. European Journal of Communication 22: 27-48.

Berganza R (2008) Medios de comunicación, ‘espiral del cinismo' y desconfianza política. Estudio de caso de la cobertura mediática de los comicios electorales europeos. ZER 25: 121-139.

Berganza R (2009) Framing the European Union and building the media agenda: The 2004 European Parliament elections in the Spanish press. Journal of Political Marketing 8(1): 59-69.

Berganza R, Van Dalen A and Chaparro MA (2010) La percepción mutua de las relaciones entre periodistas parlamentarios y miembros del Congreso y de su influencia en las agendas política y mediática. Revista de Comunicación 9: 7-25.

Blumler JG (1997) Origins of the crisis of communication for citizenship. Political Communication 1: 395-404.

Blumler JG and Kavanagh D (1999) The third age of political communication: Influences and features. Political Communication 16: 209-230

Brandenburg H (2005) Political bias in the Irish media: A quantitative study of campaign coverage during the 2002 general election. Irish Political Studies 20(3): 297-322.

Brants K, De Vreese CH, Möller J and Van Praag P (2010) The real spiral of cynicism? Symbiosis and mistrust between politicians and journalists. The International Journal of Press/Politics 15(1): 25-40.

Canel MJ, Holtz-Bacha C and Mancini P (2007) Conflict as a frame in television coverage of politics: A comparative study in Italy, Spain, and Germany. Paper presented at the annual meeting of the International Communication Association, San Francisco CA, 23 May.

Cappella JN and Jamieson KH (1997) Spiral of Cynicism. The Press and the Public Good. Oxford: Oxford University Press.

Cohen J (2008) The Presidency in the Era of 24 Hour News. Princeton, NJ: Princeton University Press.

D'Alessio D and Allen M (2000) Media bias in presidential elections: A meta-analysis. Journal of Communication 50(4): 133-156.

De Vreese CH (2005) News framing: Theory and typology. Information Design Journal + Document Design 13(1): 51-62.

De Vreese CH (2008) News coverage politics. In: Kaid LL and Holtz-Bacha C (eds) Encyclopedia of Political Communication, Vol. 2. Los Angeles, CA: SAGE, 496-501.

De Vreese CH and Tobiasen M (2007) Conflict and identity. Explaining turnout and antiintegrationist voting in the Danish 2004 elections for the European Parliament. Scandinavian Political Studies 30: 87-111.

De Vreese CH, Banducci SA, Semetko HA and Boomgaarden HG (2006) The news coverage of the 2004 European Parliamentary election campaign in 25 countries. European Union Politics 7: 477-504.

Druckman JN and Parkin M (2005) The impact of media bias: How editorial slant affects voters. Journal of Politics 67(4): 1030-1049.

Dunaway J (2009) Corporate media ownership and negativity in political news coverage. Paper presented at the annual meeting of the Southern Political Science Association, New Orleans LA, 7 January.

Engesser E and Reinemann C (2001) Können sich Aussagen und Beiträge widersprechen? Die Relevanz sozialpsychologischer Erkenntnisse zur Personenwahrnehmung für die inhaltsanalytische Tendenzmessung. In: Wirth W and Lauf E (eds) Inhaltsanalyse, Perspektiven, Probleme, Potentiale. Köln: Von Halem, 218-233.

Entman R (2007) Framing bias: Media in the distribution of power. Journal of Communication 57: 163-173. 
Eshbaugh-Soha M (2010) The tone of local presidential news coverage. Political Communication 27(2): 121-140.

Esser F and Pfetsch B (eds) (2004) Comparing Political Communication. Theories, Cases, and Challenges. New York: Cambridge University Press.

Farnsworth SJ and Lichter RS (2011) The Nightly News Nightmare: Television's Coverage of US Presidential Elections, 1988-2008, 3rd edn. Lanham, MD: Rowman and Littlefield.

Flegel R and Chaffee S (1971) Influences of editors, readers, and personal opinions on reporters. Journalism Quarterly 48: 645-651.

Freedman P and Goldstein K (1999) Measuring media exposure and the effects of negative campaign ads. American Journal of Political Science 43(4):1189-1208.

Galtung J and Ruge MH (1965) The structure of foreign news. Journal of Peace Research 2(1): 64-91.

Geer JG (2006) In Defense of Negativity: Attack Ads in Presidential Campaigns. Chicago, IL: University of Chicago Press.

Gunther R and Mughan A (eds) (2000) Democracy and the Media. A Comparative Perspective. Cambridge: Cambridge University Press.

Hallin DC and Mancini P (2004) Americanization, globalization, and secularization: Understanding the convergence of media systems and political communication. In: Esser F and Pfetsch B (eds) Comparing Political Communication. Theories, Cases, and Challenges. Cambridge: Cambridge University Press, 25-44.

Inglehart R (2000) Globalization and postmodern values. The Washington Quarterly 23(1): 215-228.

Just M, Crigler A and Buhr T (1999) Voice, substance, and cynicism in presidential campaign media. Political Communication 16: 25-44.

Kahn KF and Kenney PJ (2002) The slant of the news: How editorial endorsements influence campaign coverage and citizens' views of candidates. The American Political Science Review 96(2): 381-394.

Kepplinger HM (1998) Demontage der Politik in der Informationsgesellschaft. Freiburg: Alber.

Kepplinger HM (2011) Realitaetskonstruktionen. Wiesbaden: VS Verlag.

Kerbel MR (1999) Remote and Controlled: Media Politics in a Cynical Age, 2nd edn. Boulder, CO: Westview Press.

Kerrick J, Anderson T and Swales L (1964) Balance and the writer's attitude in news stories and editorials. Journalism Quarterly 41: 207-215.

Kleinnijenhuis J (2008) Negativity. In: Donsbach W (ed.) The International Encyclopedia of Communication. Malden, MA: Blackwell, 3188-3192.

Kleinnijenhuis J, Scholten O, Van Atteveldt WH et al. (2007) Nederland vijfstromenland: De rol van de media en stemwijzers bij de verkiezingen in 2006 [The Netherlands, a country with five rivers: The role of the media and the online test for party preferences in the 2006 elections]. Amsterdam: Bert Bakker.

Lengauer G (2007) Postmoderne Nachrichtenlogik. Redaktionelle Politikvermittlung in medienzentrierten Demokratien. Wiesbaden: VS Verlag.

Lengauer G and Vorhofer H (2010) Wahlkampf am und abseits des journalistischen Boulevards: Redaktionelle Politikvermittlung im Nationalratswahlkampf 2008. In: Plasser F (ed.) Politik in der Medienarena. Vienna: Facultas, 145-192.

Lichter RS (2001) A plague on both parties. Substance and fairness in TV election news. International Journal of Press/Politics 6(3): 8-30.

López-Escobar E, Sádaba T and Zugasti R (2008) Election coverage in Spain: From Franco's death to the Atocha massacre. In: Strömbäck J and Kaid LL (eds) The Handbook of Election News Coverage around the World. New York: Routledge, 175-191.

Matthes J and Kohring M (2008) The content analysis of media frames: Toward improving reliability and validity. Journal of Communication 58: 258-279.

Maurer M and Reinemann C (2006) Medieninhalte. Eine Einführung. Wiesbaden: VS Verlag. 
Moy P and Pfau M (2000) With Malice toward All? The Media and Public Confidence in Democratic Institutions. Westport, CT: Praeger.

Neuman RW, Just MR and Crigler AN (1992) Common Knowledge: News and the Construction of Political Meaning. Chicago, IL: University of Chicago Press.

Neveu E (2002) The four generations of political journalism. In: Kuhn R and Neveu E (eds) Political Journalism. New Challenges, New Practices. London: Routledge, 22-43.

Niven D (2001) Bias in the news: Partisanship and negativity in media coverage of presidents George Bush and Bill Clinton. International Journal of Press/Politics 6(3): 31-46.

Norris P (2000) A Virtuous Circle. Political Communication in Postindustrial Societies. Cambridge: Cambridge University Press.

Patterson TE (1994) Out of Order. New York: Vintage.

Patterson TE (2000) Doing Well and Doing Good: How Soft News and Critical Journalism are Shrinking the News Audience and Weakening Democracy - and What News Outlets Can Do About it. Joan Shorenstein Center on the Press, Politics and Public Policy. Cambridge, MA: Harvard University.

Patterson TE (2002) The Vanishing Voter. Public Involvement in an Age of Uncertainty. New York: Knopf.

Plasser F, Pallaver G and Lengauer G (2009) Die (trans-)nationale Nachrichtenlogik in Mediendemokratien. Politischer TV-Journalismus im Wahlkampf zwischen transatlantischer Konvergenz und nationaler Divergenz. In: Marcinkowski F and Pfetsch B (eds) Politik in der Mediendemokratie. PVS-Sonderheft. Wiesbaden: VS Verlag, 174-202.

Project for Excellence in Journalism (1998) Framing the News. The Triggers, Frames, and Messages in Newspaper Coverage. A Study of the Project for Excellence in Journalism and Princeton Survey Research Associates. Washington. Available at: www.journalism.org/ node $/ 445$

Puglisi R and Snyder JM (2008) Media coverage of political scandals. Paper presented at the Meeting of the Midwest Political Science Association, Chicago IL, 3 April.

Ridout T and Franz M (2008) Evaluating measures of campaign tone. Political Communication 2: $158-179$.

Roessler P (2005) Inhaltsanalyse. Konstanz: UTB.

Rosengren KE (1974) International news: Methods, data and theory. Journal of Peace Research 11(2): 145-156.

Rozell MJ (1996) The Press and the Bush Presidency. Westport, CT: Praeger.

Sabato LJ (1991) Feeding Frenzy. New York: Free Press.

Salgado S (2010) Os Candidatos Presidenciais: Construção de Imagens e Discursos nos Media [The presidential candidates: The construction of images and discourse by the media]. Coimbra: Minerva Coimbra.

Sandnes M (2004) Det personlige vinklingspress - En innholdsanalyse av norske og svenske avisers dekning av politiske valgkamper i tidsrommet 1953-1998 [The personal spin - A content analysis of the electoral coverage in the Norwegian and Swedish press from 1953 to 1998]. Hovedoppgave. SamPol: Universitetet i Bergen.

Schuck A, Vliegenthart R and De Vreese CH (2010) Who's afraid of conflict? How conflict framing in campaign news coverage mobilized voters in the 2009 European Parliamentary elections. Paper presented at the bi-annual Conference of the European Communication Research Association (ECREA), Hamburg, Germany, 12-15 October.

Schudson M (1999) Social origins of press cynicism in portraying politics. American Behavioral Scientist 42(6): 998-1008.

Semetko HA and Valkenburg PM (2000) Framing European politics: A content analysis of press and television news. Journal of Communication 50(2): 93-109. 
Sheafer T and Dvir-Gvirsman S (2010) The spoiler effect: Framing attitudes and expectations toward peace. Journal of Peace Research 47(2): 205-215.

Sheafer T and Gabay I (2009) Mediated public diplomacy: A strategic contest over international agenda building and frame building. Political Communication 26(4): 447-467.

Sheafer T, Weimann G and Tsfati Y (2008) Campaigns in the Holy Land: The content and effects of election news coverage in Israel. In: Strömbäck J and Kaid LL (eds) The Handbook of Election News Coverage around the World. New York: Routledge, 209-225.

Shenav SR and Sheafer T (2008) From inter-party debate to inter-personal polemic: Media coverage of internal and external party disputes in Israel, 1949-2003. Party Politics 14(6): 706-725.

Shoemaker PJ and Vos TP (2009) Gatekeeping Theory. New York: Routledge.

Strömbäck J (2005) Commercialization and the media coverage of Swedish national elections in 1998 and 2002. Paper presented at the annual meeting of the American Political Science Association, Washington, 1 September.

Strömbäck J (2008a) Den medialiserade valbevakningen [Electoral monitoring by the media]. In: Nord L and Strömbäck J (eds) Väljarna, partierna och medierna. En studie av politisk kommunikation $i$ valrörelsen 2006 [The electorate, parties, and the media. A political communication study of the 2006 elections]. Stockholm: SNS Förlag, 127-167.

Strömbäck J (2008b) Swedish election news coverage: Towards increasing mediatization. In: Strömbäck J and Kaid LL (eds) The Handbook of Election News Coverage around the World. New York: Routledge, 160-174.

Strömbäck J and Dimitrova DV (2006) Political and media systems matter. A comparison of election news coverage in Sweden and the United States. Harvard International Journal of Press/ Politics 11(4): 131-147.

Strömbäck J and Luengo OG (2008) Polarized pluralist and democratic corporatist models: A comparison of election news coverage in Spain and Sweden. International Communication Gazette 70: 547-562.

Valentino N, Beckmann MN and Buhr TA (2001) A spiral of cynicism for some: The contingent effects of campaign news frames on participation and confidence in government. Political Communication 18: 347-367.

Van Aelst P, Brants K, Van Praag P, De Vreese CH, Nuytemans M and Van Dalen A (2008) The Fourth Estate as superpower? An empirical study of perceptions of media power in Belgium and the Netherlands. Journalism Studies 9(4): 494-511.

Van Gorp B (2005) Where is the frame? Victims and intruders in the Belgian press coverage of the asylum issue. European Journal of Communication 20(4): 484-507.

Vliegenthart R, Boomgaarden HG and Boumans JW (2011) Changes in political news coverage: Personalization, conflict and negativity in British and Dutch newspapers. In: Brants K and Voltmer K (eds) Political Communication in Postmodern Democracy. Challenging the Primacy of Politics. London: Palgrave Macmillan, 92-110.

Wayne M and Murray C (2009) UK television news: Monopoly politics and cynical populism. Television \& New Media 10(5): 416-433.

Weintraub AE and Pinkleton BE (1995) Positive and negative effects of political disaffection on the less experienced voter. Journal of Broadcasting \& Electronic Media 39(2): 215-235.

Westen D (2007) The Political Brain. New York: Public Affairs.

Westerstahl J and Johansson F (1986) News ideologies as moulders of domestic news. European Journal of Communication 1: 133-149.

Wilke J and Reinemann C (2007) It's the debates, stupid! How the introduction of televised debates changed the portrayal of chancellor candidates in the German press, 1949-2005. Harvard International Journal of Press/Politics 12: 92-111. 
Zaller JR (1999) A Theory of Media Politics. How the Interests of Politicians, Journalists, and Citizens Shape the News. Unpublished manuscript. Available at: www.sscnet.ucla.edu/polisci/ faculty/zaller/media\%20politics\%20book\%20.pdf

\section{Biographical notes}

Günther Lengauer ( $\mathrm{PhD}$ in Political Science, University of Innsbruck) is Senior Post-Doc Researcher and Principal Investigator of the Austrian National Election Study at the LeopoldFranzens University of Innsbruck, Austria.

Frank Esser ( $\mathrm{PhD}$ in Mass Communication, University of Mainz) is Professor of International and Comparative Media Research in the Department of Mass Communication and Media Research at the University of Zurich. He is also co-director of the Swiss National Competence Center in Research on Democracy (NCCR Democracy).

Rosa Berganza ( $\mathrm{PhD}$ in Journalism, University of Navarra) is Professor and Chair of Theory of Communication and Political Communication at the Faculty of Communication at University Rey Juan Carlos (URJC), Madrid, Spain. 